\title{
An improved enzyme assay for molybdenum-reducing activity in bacteria.
}

\begin{abstract}
Molybdenum-reducing activity in the heterotrophic bacteria is a phenomenon that has been reported for more than 100 years. In the presence of molybdenum in the growth media, bacterial colonies turn to blue. The enzyme(s) responsible for the reduction of molybdenum to molybdenum blue in these bacteria has never been purified. In our quest to purify the molybdenum-reducing enzyme, we have devised a better substrate for the enzyme activity using laboratory-prepared phosphomolybdate instead of the commercial 12phosphomolybdate we developed previously. Using laboratory-prepared phosphomolybdate, the highest activity is given by 10:4-phosphomolybdate. The apparent Michaelis constant, $\mathrm{K}$ $\mathrm{m}$ for the laboratory-prepared 10:4-phosphomolybdate is $2.56 \pm 0.25 \mathrm{mM}$ (arbitrary concentration), whereas the apparent $\mathrm{V}$ max is $99.4 \pm 2.85$ nmol Mo-blue min-1 mg-1 protein. The apparent Michaelis constant or $\mathrm{K} \mathrm{m}$ for $\mathrm{NADH}$ as the electron donor is $1.38 \pm 0.09 \mathrm{mM}$, whereas the apparent $\mathrm{V} \max$ is $102.6 \pm 1.73 \mathrm{nmol}$ Mo-blue min-1 mg-1 protein. The apparent $\mathrm{K} \mathrm{m}$ and $\mathrm{V}$ max for another electron donor, NADPH, is $1.43 \pm 0.10$ $\mathrm{mM}$ and $57.16 \pm 1.01 \mathrm{nmol}$ Mo-blue min $-1 \mathrm{mg}-1$ protein, respectively, using the same batch of molybdenum-reducing enzyme. The apparent $\mathrm{V}$ max obtained for NADH and 10:4phosphomolybdate is approximately 13 times better than 12-phoshomolybdate using the same batch of enzyme, and hence, the laboratory-prepared phosphomolybdate is a much better substrate than 12-phoshomolybdate. In addition, 10:4-phosphomolybdate can be routinely prepared from phosphate and molybdate, two common chemicals in the laboratory.
\end{abstract}

Keyword: Assay; Mo-reducing enzyme; Molybdate; Phosphomolybdate; Molybdenum blue. 